\title{
Artificial insemination in rabbits: factors that interfere in assessing its results
}

\author{
Farid Soliman • Karim El-Sabrout
}

F Soliman - K El-Sabrout (Corresponding author)

Department of Poultry Production, Faculty of Agriculture (ElShatby), Alexandria University, Alexandria, Egypt. email: kareem.badr@alexu.edu.eg

Received: January 24, 2020 • Accepted: February 23, 2020 • Published Online: February 28, 2020

\begin{abstract}
Understanding the rabbit's sexual behavior and reproduction process is very important when using artificial insemination (AI) instead of natural mating in intensive rearing systems. Ovulation in rabbit females not occur spontaneously/ induced ovulatory animals, but it has to be induced through a neuro-hormonal reflex, which is stimulated during mating. The mating effect of satiety on specific measures of rabbit female sexual behavior has not been investigated. When applying AI, in the absence of a male, ovulation has to be induced by exogenous hormonal analogs. Bio-stimulation techniques are suggested as a substitute for hormones in that respect. One of the most effective approaches to distribute ejaculates from bucks of superior quality or genetic value is the systematic use of AI in intensive rabbit production. Rabbit's sexual receptivity has a significant influence on fertility at insemination. In addition, a limitation factor for rabbit AI spread is related to their semen preservation. Fresh diluted semen has been used but its quality can be maintained only for a short period. However, there are few articles available have indicated the negativity of AI usage on rabbit, and the factors that can influence the AI process including the sexual desire behavior. Therefore, the objective of this review is to identify the important factors that directly or indirectly affect AI process success, meanwhile interfering with and/or relying on AI assessment.
\end{abstract}

Keywords: bio-stimulators, natural mating, semen collection, sexual behavior, welfare

\section{Introduction}

The world population has constantly grown, as expected will reach more than eight billion in 2030, and maybe more than 9 billion in 2050. This will require an increase in food production of nearly 50 percent. Therefore, the world will be required more than $50 \%$ increase in global meat production (da Costa et al 2011). The rabbit is a good potential meat source as a solution to fulfill demand for animal proteins (Mailafia et al 2010; Daader et al 2016). With an intensive breeding program, a rabbit doe (female) can be expected to produce 60 weaned young per year, representing a total of $120 \mathrm{~kg}$ rabbit meat at market age (Lukefahr and Cheeke 1990). Moreover, rabbits have a high reproductive rate compared to other livestock. They become sexually mature earlier, relatively short gestation period, produce higher litter size at birth and can be rebred immediately after kindling and short generation interval (Hassan et al 2012).

The artificial insemination (AI) of rabbit females appear on European farms in the late 1980's (Theau-Clement 2007). It used previously to obtain the genetic improvement of the animals and to solve sanitary problems. However, significant improvements in both productive and economical aspects were later achieved, such as the acceleration of the desirable traits of high genetic value, which supported by the use of biotechnologies for semen and embryos preservation (da Costa et al 2011).

Maintaining animals by improper management includes some certain negative effects may cause abnormal behavior (Lawrence and Rushen 1993). Understanding rabbit behavior is necessary to determine their needs and the consequent adaptation of commercial rearing systems include AI. Normal behavior is among animal welfare regulations identified by the Farm Animal Welfare Council (FAWC 2001). For appropriate evaluation of rabbit welfare, physiology parameters, disease, behavior and performance indicators should be considered (Trocino and Xiccato 2006). Additionally, understanding factors affect rabbit sexual behavior is very important because they influence its sexual efficiency directly (El-Sabrout 2017). In general, there are few articles available have indicated the negativity of AI usage on rabbit, and the factors that can influence the AI process including the sexual desire behavior. Therefore, the objective of this review is to identify the important factors that directly or indirectly affect AI process success, meanwhile interfering with and/or relying on AI assessment. 


\section{Natural Mating}

Rabbit's sexual behavior and breeding potential are influenced by a wide board of external and internal stimuli factors (Ajuogu and Ajayi 2010). Sexual behavior of rabbit buck consists of performing a single mount, followed by a series of pelvic thrusts during which intromission occurs, and ultimately resulting in semen ejaculation inside the doe vagina (Coy et al 2012). Rabbit bucks have a remarkable capacity for sexual activity (Jiménez et al 2012) and their average frequency of mating 2.43 in 15 minutes (Gado et al 2015). Rabbit bucks with sexually used perfectly and high-quality semen are required throughout the year to achieve maximum productivity and libido, either through AI (Rodríguez-de Lara et al 2008) or natural mating (Saleh et al 2010).

Rabbit doe is considered poly-estrus or having no cycle or regular estrus (Aduku and Olukosi 1990) and ovulation occurs after mating (Vella and Donnelly 2012). Rabbit uterus morphology represents a duplex of the uterus consisting of two separate, fully functional uterine horns and cervices opening into a single vagina (Fischer et al 2012). Periods of doe receptivity last anywhere from 5 to 14 days and are followed by one to two days in which the doe will refuse mating with buck (Vella and Donnelly 2012). Rabbit does are in heat (estrus) when their vulva is wet, red or slightly violet color and swollen (Maertens and Luzi 1995; Szendrő et al 2006), this is followed by the peak luteinizing hormone (LH) in their blood (Maertens et al 1983).

In natural mating, the breeder enters the female into the male cage, since they live commercially in separately. Natural mating is common and suitable on small and medium farms with less than 100 does (Szendrö et al 2012). Ovulation occurs in the ovaries between 10 and $13 \mathrm{~h}$ after mating (Vella and Donnelly 2012). Within the same time, the sperm move inside the doe reproductive system to the fertilization area (ampule) to meet oocyte and fertilization takes place (Coy et al 2012). The fertilization rate is generally high, about $95 \%$ (Peiró et al 2007).

\section{Artificial Insemination}

Artificial insemination technique, in general, showed to be most suitable for both small and large commercial rabbit farms than natural mating (Shuji 2009). In the last two decades, the productivity of rabbit farms has increased by the implementation of AI due to intensive cycled production and genetic selection for increased prolificacy (Castellini et al 2010). However, AI is commonly used at large rabbit farms in Europe and include five steps: collecting semen from the bucks, examining the semen visually and microscopically, dilution of semen 10 to 20 times, inseminating does by pipette, and injecting Gonadotropin-Releasing Hormone $(\mathrm{GnRH})$ analog into the hind leg muscle at the moment of insemination (Szendrö et al 2012). Rabbit reproduction in most European farms carried out by AI, known as "single batch". In this system, all rabbit does subjected to a specific intervention on the same day (e.g. all does are inseminated on one day), and the next will takes place 6 wks later. Here the economic value of fertility is increased since the doe that was not fertilized will remains not pregnant for $6 \mathrm{wks}$ (TheauClémen et al 2015). Consequently, the palpation, parturition and kits weaning make on the same day.

In France, the rabbit does in over $90 \%$ of the farms are inseminated 11 days after parturition (Azard 2006). This is known as the 42-d reproduction cycle, which comprises the gestation period (31 days) and time for rebred (thereafter 11 days). In this case, kits are weaned at 28 to 32 days of age and the growing rabbits are sold at the age of 70 to 74 days, with average weight from 2.4 to $2.5 \mathrm{~kg}$ (Jentzer 2008). From the animal welfare viewpoint, the 56-d cycle was more favorable than 42-d cycle, for doe body condition and survival of does, but number of kits/doe/year of the $42-\mathrm{d}$ exceeded that of the $56-\mathrm{d}$ by 19 to $23 \%$ which has a high economic impact the rabbitry benefits (Szendrö et al 2012).

When AI applies the does are in the lactating period, the conception rate depends on their receptivity. TheauClément et al (2006) observed a strong inverse relationship between lactation and reproductive functions in nonreceptive does. However, hormonal treatment [pregnant mare serum gonadotrophin (PMSG)] is sometimes recommended for increasing lactating doe receptivity.

\section{Factors interfered with the evaluation of AI results}

AI technology allows breeders to keep a greater number of breeding does whereas reducing the number of bucks required to be housed, thereby minimizing the spread of disease from mating and improving production rates (Morrell 1995). In addition, the AI technique includes prolonging fertility during hot times of the year, better breeding programs, favorable gene selection, health monitoring improvements and finally cycle-based production (Carluccio et al 2004), and rabbit embryo developmental (Obasi et al 2016).

Several factors are affecting the AI success and reproductive performance of inseminated does (Figure 1). However, it is important to highlight that most of these factors also have an impact on the reproductive efficiency of rabbits submitted to natural mating.

\section{Doe receptivity (libido) and Buck effect}

Fertility affects greatly by sexual receptivity of rabbit does at AI, which could be induced by hormones or "biostimulation" techniques. There is high individual variability of sexual receptivity of non-lactating rabbit does maintained without any bio-stimulation or hormonal treatment (TheauClément et al 2011; 2015). The receptivity and fertility in the 
rabbit have a high phenotypic relationship (Theau-Clément 2008) whereas fertility has low heritability value (Piles et al 2004). Theau-Clémen et al (2015) found that the heritability of receptivity was 0.04 , which indicated to be not heritable, which lead to a lack of selection response. Moreover, they reported that the pseudo-pregnancies due to uncontrolled ovulations could have interfered with receptivity.
Receptive does at insemination produce three to four times more rabbits at weaning than those non-receptive ones, particularly when they are lactating (Theau-Clément 2008). Therefore, receptivity is often induced by injection of PMSG and/or bio-stimulation method (Renouf and Klein 2008). However, Theau-Clément et al (2008) showed that lower fertility would not have been compensated by PMSG due to its inefficiency in pseudo-pregnant does.

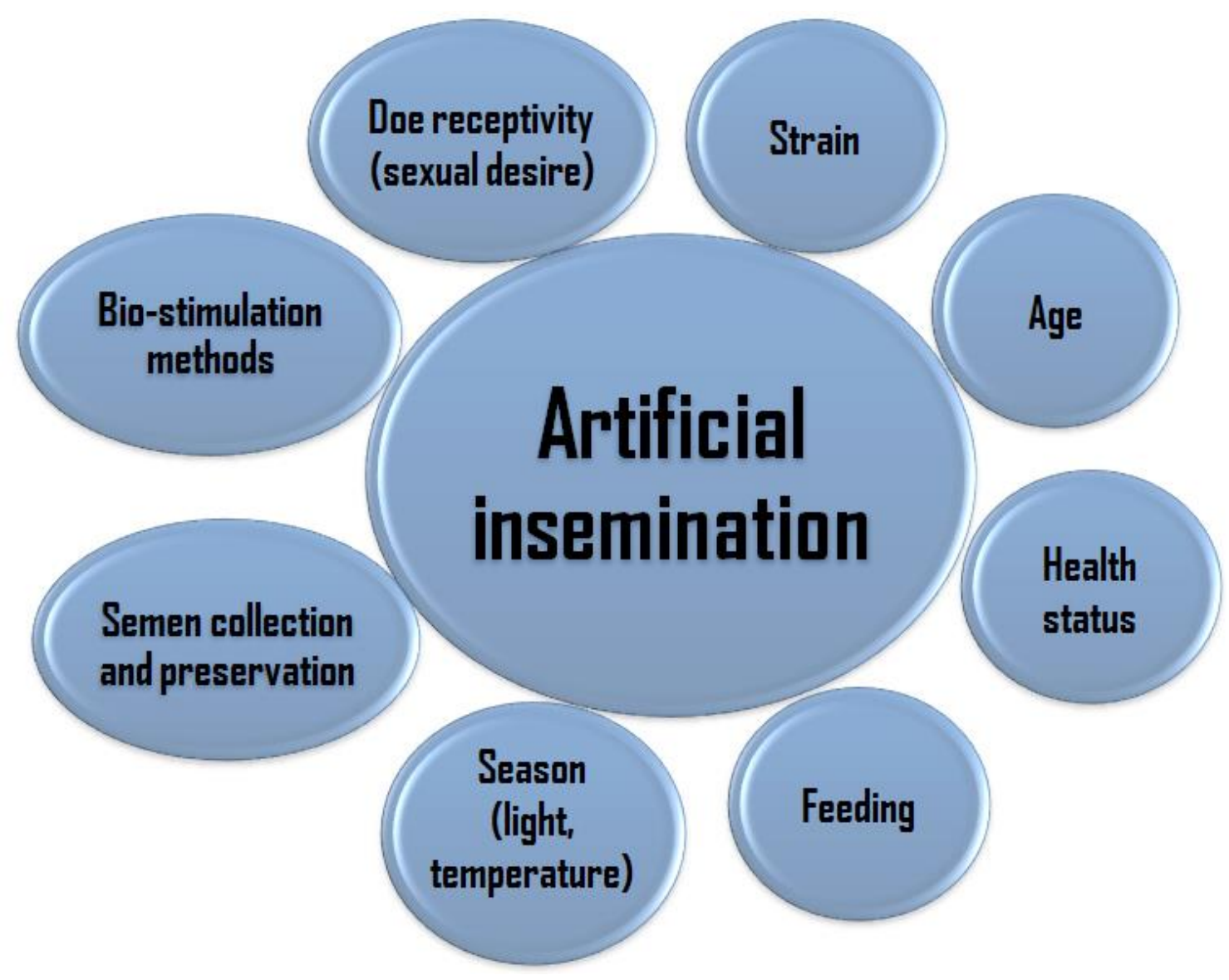

Figure 1 Factors that could affect the artificial inseminantion (AI) success.

Sexual receptivity, parity, lactation status, pseudo pregnancy (Theau-Clément et al 2012) and physiological status (Castellini 1996) affected the reproductive performance of rabbit doe at the time of insemination. Sexual receptivity is determined at the day of AI using three methods: color of vulva (red or pink represent receptive rabbit doe, while purple or white represent non-receptive rabbit doe); rectal temperature, and vagina cytology (the percentage of keratinized cells), according to Ola and Oyegbade (2012).

On the other hand, buck existence could influence the AI success. Hammond and Asdell (1926) reported early that AI followed by sterile mating resulted in a higher pregnancy rate than $\mathrm{AI}$ alone $(91 \%$ versus $4 \%$ ). The presence of rabbit buck near the doe affect the fertility of the doe was reported by Berepudo et al (1993) and Bonanno et al (2003).

Cervantes et al (2015) documented that the effect of physical/social interaction on ovulation in New Zealand White (NZW) rabbits, and did not support the hypothesis that seminal plasma stimulates ovulation in rabbits. Short-term (2 h) bio-stimulation of NZW rabbit does (exposed to male odor or an adult male) resulted in the appearance of various behavioral responses followed by differences in conception rates after routine AI (EL-Azzazi et al 2017). In addition, high reproductive performance in the inseminated rabbit does is depends on the physiological and behavioral experience of does at the time of insemination (Theau-Clément 2007). The 
lower rates of receptive does with AI result in a less successful insemination process (Theau-Clément et al 2015).

In a recent study, Ola and Oyegbade (2012) reported that does exposed to visual contact with the buck (in conjunction with olfactory and auditory contacts) showed reddish or pinkish vulva most of the time, an indication of high state of sexual receptivity. It has been concluded that certain male signs other than mating can also stimulate ovulation in the doe rabbit. Ola and Olatunbosun (2013) indicated the buck's presence improved the doe's sexual receptivity. However prolonged visual and/or tactile contacts between the two opposite sex appeared to be detrimental to the breeding efficiency and overall productivity of the doe.

In respect of bucks, authors suggest that rabbits exchange sex pheromones of either male or female origin to influence reproductive behavior in the opposite sex (Hudson and Distel 1990; McNitt 1992). Introductions of female pheromones cause significant elevation in male sex hormones that regulate spermatogenesis in male Syrian hamsters (Richardson et al 2004). Pheromones are chemical elements emitted by one individual and received by another from the same species, raises different behavioral and endocrine activities (Hegab et al 2015). Rabbit doe exposure of bucks could be a low-cost bio-stimulation option that benefits AI in commercial rabbit farms by improving buck rabbit's reproductive performance (improves sexual drive, sperm production and quality).

\section{Light effect, bio-stimulation methods, and PMSG}

To increase receptivity and conception rates at 11 days after kindling, rabbit does are generally treated $2-3 \mathrm{~d}$ prior to AI by PMSG. The PMSG treatment, depending on the dose and frequency, may induce antibody production which can negatively influence the kindling rate, and in consequence, culling rate will increase (Castellini 1996; Theau-Clément 2007). For these reasons, researchers and breeders would like to replace the PMSG with alternative bio-stimulation methods.

The optimal interval between PMSG injection and AI was studied by Alvariño (2005) that concluded that fertility decreases when the interval reaches $96 \mathrm{~h}$, without any significant differences of fertility from 24 to 72 hours. Moreover, Rebollar et al (2006) found a positive effect of PMSG only during the first four injections. It is commonly accepted that a dose of 20-25 IU of PMSG at $48 \mathrm{~h}$ before insemination of lactating does at 11 days post-partum increases the percent of receptive does at insemination. In addition to their high costs, the use of hormones has become unfavorable from the welfare point. The PMSG has been used for about 15 years to synchronize rabbit doe estrus (Daader et al 2016). For the previous conditions, researchers and breeders would like to replace the PMSG treatments with alternative bio-stimulation methods (Theau-Clément 2007), some of these methods already used in practice, such as dam-litter separations prior to insemination, changing the nursing method or lighting schedule.

Sexual bio-stimulation methods (act through sensory signals) have their effect on both receptivity and fertility of rabbit does. The hormonal regulation of receptivity in rabbit does showed to be strongly related to estrogen levels, as it is generally used to assess follicular growth and ovarian functions (Marongiu and Dimauro 2013). Bio-stimulated rabbit does yielded higher pregnancy rates and litter size at birth and at weaning compared to untreated does. Different bio-stimulation techniques have been used effectively in initiating and enhancing the sexual behavior and reproductive cycles in rabbits (Rodríguez-de Lara et al 2010; GonzálezMariscal et al 2015). Furthermore, the number of offspring produced in a litter is the result of the interaction of several variables including both maternal and male effects (Schmidova et al 2016).

It was proven that increasing the daily lighting schedule from 8 to $16 \mathrm{~h} 7-8 \mathrm{~d}$ prior to AI leads to higher receptivity and kindling rates (Gerencsér et al 2008; Matics et al 2012) and kindling rate (Szendrő et al 2016). However, Maertens and Luzi (1995) increased the lighting period from 10 to $16 \mathrm{~h}$ /day five days before doe AI but there is no significant change observed in the conception rate. Normal program of light (16 Light: 8 Dark) is optimal and has no significant effect on effect on any reproductive traits of inseminated rabbit does compared with different examined light programs (Gerencsér et al 2012) and also semen reproductive traits of bucks (Marai et al 2002). Gerencsér et al (2008) concluded that light stimulation could be an alternative to PMSG treatments. Daily lighting period, in general, differs according to year-seasons. Rodríguez-de Lara et al (2010) showed that semen characteristics of rabbit bucks differed by season and reproductive potential in spring was significantly greater than those in winter.

In addition, Szendrö et al (2016) reviewed that rabbits are able to see well during the night; however, their color vision is restricted. Rabbits which exposed to a periodic light and dark environment generate a $24 \mathrm{~h}$ rhythm of their body functions. Moreover, Gerencsér et al (2011) suggested that light color's effect on the rabbit production can be perspective. According to the literature the rabbits perceive the red light (its wavelength) less compared to other light colors. In general, bio-stimulation methods are very natural and less expensive compared to the hormonal treatments (Lorenzo et al 2014).

\section{Vaginal barrier and seminal plasma}

Rabbit vaginal fluids have some amount of water since any substance intended for vaginal delivery requires a certain 
degree of solubility (Hussain and Ahsan 2005). Recently, the GnRH recommended adding directly to the seminal dose of AI. This method provides new perspectives on the absorption capacity of different $\mathrm{GnRH}$ analogs from the doe reproductive system, meanwhile reducing the time of hormone injections and improving the welfare of rabbit does (Quintela et al 2009). Factors represent a vaginal barrier such as the dissolution degree in vaginal lumen, the membrane thickness, the degradation or blockage due immunoglobulins, cytokines, proteases, the leucocytosis, the fast or slow transport to the uterus by means muscle contractions, the hormone profile, the conductivity, etc. (Vicente et al 2008; Rebollar 2011). In addition, factors influencing the absorption of GnRH by the vaginal mucosa include the state of the mucosa (affected by sexual receptivity), extender composition and the capability of sperm to incorporate foreign molecules (Vicente et al 2008).

$\mathrm{GnRH}$ is a hypothalamic multi-peptide that plays a necessary role in the regulation of reproductive processes (Conn and Crowley 1994). GnRH is a member of a larger family of peptides that is present in every vertebrate class examined thus far (Tsai and Zhang 2008). Several GnRH analogs with different pharmacological properties and potencies are commercially available, such as triptorelin, leuprolide, buserelin, gonadorelin, dalmarelin, etc. are used to induce ovulation in rabbit does. The PMSG and GnRH application studied by Dimitrova et al (2009) showed that fertility was $28.57 \%$ when applied only GnRH, while it was $62.50 \%$ when both applied. Furthermore, NZW does showed higher level of fertility then Californian does.

Seminal plasma also contains other particles of different size which affect the spermatozoa behavior during the transit along the female reproductive tract. Strain, feeding, health status, rearing condition, season, age and collection frequency are most factors of affected seminal characteristics, thus contributing to the large variability in semen traits (Alvariño 2000). Paolicchi et al (1999) suggested that some factor(s) in the seminal plasma could contribute to the secretion of LH and, consequently to the induction of ovulation in receptive rabbit doe. Ratto et al (2010) have concluded that ovulation-inducing factor in seminal plasma is a protein molecule that is resistant to heat and enzymatic digestion with proteinase $\mathrm{K}$, and has a molecular mass approximately $30 \mathrm{kDa}$. The stimulatory chemical compound in seminal plasma which ovulation-inducing effect is a protein called beta nerve growth factor ( $\beta-\mathrm{NGF})$. It is suggested that $\beta$-NGF (ovulation-inducing factor, OIF) induces its effects on the hypothalamo- pituitary axis (Adams et al 2016). This protein was found in abundant amount in rabbit seminal plasma and induced ovulation in $80 \%$ of female alpacas following administration of $1 \mathrm{mg}$. (Kershaw-Young et al 2012). It was concluded that $\beta$-NGF may provide an alternative mechanism for the induction of ovulation in alpacas and; reduces the need for synthetic hormones and partially improves fertility in combination with AI. In addition, Silva et al (2015) mentioned that $\beta$-NGF from llama seminal plasma origin stimulate level followed by ovulation and the development of functional corpora lutea, regardless of the route of administration. Adams et al (2016) reported that the ovulatory response to $\beta$-NGF seminal plasma in llamas and alpacas is brought an increase of LH level in the bloodstream and their function depend on the degree of absorption of this factor from the genital mucosa into circulation and not a response to physical stimulation of the tubular genitalia itself.

\section{Semen quality and site of insemination}

Generally, the success in AI depends on many factors as semen quality, insemination dose, live and normal spermatozoa percentages, duration between semen collection and AI and depth of semen deposition in the female reproductive tract (Boiti et al 2005) and also receptive females and perfect inseminator (Rowida et al 2016). The rabbit vagina is a favorable environment for prolonged sperm survival, after mating or AI, sperm capable of fertilization are transported beyond the cervices leaving the seminal plasma behind (Drobniz and Overstreet 1992). Only 5\% of semen deposited transported beyond the uro-vaginal valve (Overstreet and Cooper 1978). The vagina, cervix, and uterus each maintain a population of progressively motile spermatozoa for at least 16 $\mathrm{h}$ after mating, by which time ovulation occur and $98 \%$ of oocytes are fertilized (Cooper et al 1979). Therefore, one of the most important factors associated with high fertility with $\mathrm{AI}$ is the site of semen deposition inside the doe vagina. There is a difference in the length of the rabbit vagina which was showed to be $10.0 \mathrm{~cm}$ (Frandson 1981), $20.8 \mathrm{~cm}$ (Morrell 1995), 14 to $19 \mathrm{~cm}$ long (Rebollar 2011), and 14.5 to $19.5 \mathrm{~cm}$ (Rowida et al 2016). These differences may be due to strain and age of rabbit does. Louis (2009) found that the pipette should be inserted $10-15 \mathrm{~cm}$ into rabbit vagina to ensure good fertility. The optimal number of spermatozoa per insemination will vary upon the procedures to which the spermatozoa are subjected prior to storage (Farrell et al 1993) and their motility (Lavara et al 2005). The good required insemination dose depends on semen handling as diluters and preservation storage time as well as the genetic strain and physiologic state of the female (Brun et al 2002). It showed to be $0.5 \mathrm{ml}$ of diluted fresh semen containing about $1.6 \times 10^{6}$ motile sperm (Chen et al 1989), more than $50 \times 10^{6}$ motile sperm (Seleem 2003), diluted 1:3 with $80-100 \times 10^{6}$ spermatozoa $/ \mathrm{ml}$ (LópezGatius et al 2005), diluted 1:5 with $6 \times 10^{6}$ spermatozoa/ ml (Lavara et al 2005), diluted 1:6 with $60 \times 10^{6}$ spermatozoa $/ \mathrm{ml}$ (Zeidan et al 2008). Rowida et al (2016) found that increasing the number of spermatozoa $\left(45.04 \times 10^{6 / 0.5} \mathrm{ml}\right)$ in dilution rate $1: 5$ and deposit inter vagina at $12 \mathrm{~cm}$ improved conception and kindling rates while litter size was not affected. 
Sperm numbers required for optimal fertility can be reduced in case of deep vaginal-cervical insemination as an important factor in commercial AI of rabbits (Tantasuparuk et al 2011). Moreover, Anderson et al (2004) and Kurykin et al (2006) reported that a low number of spermatozoa significantly increased the pregnancy rate, when the semen deposited in the uterus. On the other hand, Chelmońska et al (2007) showed that deep insertion of the posterior region of the uterus creates unfavorable conditions for spermatozoa and consequently, fertility efficacy. According to Araujo et al (2013), using suitable insemination dose and dilution rate are very important because very small volumes may result in less effective mechanical drainage, while highly concentrate semen may be more irritating because of more contacts between spermatozoa and endometrium, resulting in an intense inflammatory response. Theau-Clément et al (2016) showed that the presence or absence of gel, volume, percentage of progressive sperms, curvilinear velocity and beat frequency of the flagellum, did not affect fertility or productivity of inseminated INRA1001 rabbit doe. However, mass motility and the percentage of motile cells (>84\%) significantly influenced rabbit doe productivity, but there was a non-linear relationship. On the other hand, Ndors et al (2015) showed that three/day AI frequency with NZW does has significantly better conception and litter size compared to $1 /$ day and 2/day frequencies. However, gestation length and litter weight traits were not significantly affected.

\section{Preservation of rabbit semen}

Commercial rabbit meat production is usually used AI with fresh diluted semen, yielding pregnancy rates similar to natural mating (Morrell 1995) and performed within 6-12 h of collection (Daniel and Renard 2010). Rabbit semen preservation is one of the main problems for a wide use of AI in rabbitries (Alvariño 2000). However, the demand for stored semen to be used in AI programs of livestock animals (Zhao et al 2009) and rabbit (Di Iorio et al 2014) is increasing. Storage of rabbit semen for longer than 24 to $48 \mathrm{~h}$ causes damage of semen quality with a decrease in fertility (Rosato and Iaffaldano 2011; Di Iorio et al 2014). Rabbit spermatozoa are more sensible to hypertonic solutions, causing a reduction in storage ability and consequently a decrease in kindling rates (Seleem and Rowida 2005). Moreover, the freezing process of rabbit semen is associated with a reduction in motility, viability, and fertility or prolificacy after AI (Castellini et al 2006). This is partially due to the membrane lipid peroxidation caused to increase the level of reactive oxygen species, which in turn would affect lipids, proteins, nucleic acids and sugars within the sperm (Bansal and Bilaspuri 2011; Kim et al 2011). Moreover, rabbit semen does not respond to dilution as in other species mainly because of its sensibility to hypertonic solution, and to cry-protective agents containing hydroxyl groups such as glycerol (Ndors et al 2015).

The attempts to improve rabbit semen extenders and storage conditions to prolong the storage duration of semen still going on and the negative and positive results are obtained. Unfortunately, rabbit spermatozoa had a minimum capacity to chilling (Rosato and Iaffaldano 2011) or frozen (Mocé and Vicente 2009) storage. Echegaray-Torres et al (2004) found that the maximum period of NZW rabbit semen preservation at $15^{\circ} \mathrm{C}$ in gelatin supplemented extender was 72 $\mathrm{h}$, without affecting seminal characteristics. Adding $2 \%$ gelatin to tris-buffer extender of APRI rabbit semen enhanced freezing ability, efficiency, and fertility of spermatozoa in thawed semen (El-Sherbieny et al 2012). Similarly, LópezGatius et al (2005) and Raga-Ayat et al (2012) showed that motility and viability of spermatozoa are maintained for a longer time when gelatin is added to fresh rabbit semen extenders. Only a few reports have shown satisfactory results with frozen semen (Iaffaldano et al 2012; Rosato and Iaffaldano 2013). However, the freezing technique is more expensive and need more equipment than with chilling technique.

Of recent attempts, the results of Hong et al (2012) indicated that sperm preparation from cauda epididymis direct collection of sperm for AI was faster and more efficient for inseminated rabbits does than the conventional method. Chilled semen storage studied by Johinke et al (2015), and found that chilled with $30 \times 10^{6}$ spermatozoa/ml may provide an appropriate balance degree between motility and $\mathrm{H}_{2} \mathrm{O}_{2}$ production to best maintain overall sperm function. Additionally, Rowida et al (2015) indicated that sodium chloride is effective as a diluents to obtain good results at 37 ${ }^{0} \mathrm{C}$. The Tris extender $\mathrm{pH} 7.5$ is of great value for the preservation of NZW rabbit semen at $5{ }^{\circ} \mathrm{C}$. Moreover, the enrichment of pooled rabbit semen tris-basic extender with 1.2-1.6 mg propolis ethanolic extract $/ 5 \mathrm{ml}$ maintain the sperm characteristics in good condition all over $72 \mathrm{~h}$ of chilling (ElSeadawy et al 2017).

In addition to the genetic makeup of the rabbit (strain effect) (Heba Allah et al 2016), there are many environmental/ managements factors reported in the literature to influence the reproductive characteristics of doe and/or buck and maybe interfere with the evaluation of $\mathrm{AI}$ success, e.g. the differences in mating frequency (Ajuogu and Ajayi 2010); age of doe (Rodel et al 2004), dietary supplementations (Alsenosy and Abd El-Aziz 2019), light (Mousa-Balabel and Mohamed

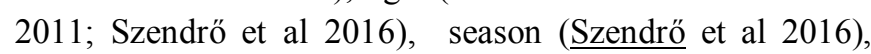
climates/heat stress (Kumar et al 2013; Marco-Jimenez et al 2013), housing (Rommers et al 2006), and suckling mortality (Hamilton et al 1997).

Finally, the overall view of the comparison between nature mating and AI in rabbits should include: (1) the 
prospective of damage caused by the use of exogenous hormones before and after AI on the hormonal status and/or reproductive functions of does. (2) Doe behavioral changes resulting from the non-practice of natural mating (buck effect/ doe libido/ doe sexual practice), which deprived them of natural sexual desire (welfare aspect matter). We may suggest further researches in the future on these two important points.

\section{Final Considerations}

Artificial insemination in rabbits (with/without hormones) has been reported in several previous studies with different rabbit's strains, applications, and environments that have been partially reviewed in this review. The AI process could be difficult for the smallholder of rabbit farms to be carried out accurately/ no potential because of the abundance of factors affecting the success of this process, in term of semen collection, dilution degree, protocol of hormone injection date, equipment, duration of semen storage, technical of AI procedure, as well as the costs of these steps. This may suggest the need for private companies for rabbit semen collection, dilution, conservation and AI application in small farms, especially in developing countries that depend on small rabbit flocks. In addition, the review confirms that $\mathrm{AI}$ is useful in large rabbit farms taking into account the factors mentioned to achieve the highest fertility results. However, further researches are needed in order to not/minimize future use of hormones (PMSG \& GnRH) for AI in rabbits, either for the availability of bio-stimulation methods to synchronize rabbit doe estrus or natural substances in seminal plasma for rabbit ovulation.

\section{Acknowledgments}

Authors of this review are grateful to their respective university for its technical assistance and valuable support in the completion of this review.

\section{Conflict of Interest}

The authors declare no conflict of interest.

\section{References}

Adams GP, Ratto MH， Silva ME， Carrasco RA (2016) Ovulation inducing factor (OIF/NGF) inseminal plasma: a review and update. Reproduction in Domestic Animals 51:4-17.

Aduku AO, Olukosi J (1990) Rabbit Management in the Tropics (Eds). Living Books Series, Au publications, Abuja, Nigeria, pp. 411 .

Ajuogu PK, Ajayi FO (2010) Breeding responses of rabbits to artificial insemination in the humid tropics. Animal Production Research Advances 6:41-42.
Alsenosy AA, Abd El-Aziz AH (2019) Effect of Garlic Supplementation to Rabbit Semen Extender on Semen Metabolic and Oxidative Markers. Alexandria Journal of Veterinary Sciences 60:94-101.

Alvariño JM (2000) Reproductive performance of male rabbits. Proc., $7^{\text {th }}$ World Rabbit Congress, Valencia, Spain: 13-35.

Alvariño M (2005) Manejo reprodutivo en cunicultura. Jornadas internacionais de cunicultura. UTAD - Vila Real, 135-144.

Anderson M, Taponema J, Koskinem E, Dahlbom M (2004) Effect of insemination with doses of 2 or 15 million frozen-thawed spermatozoa and semen deposition site on pregnancy rate in dairy cows. Theriogenology 61:1583-1588.

Araujo AG, Brandao FZ, Guedes MC, Pinaffi FL, Silva LA, Torres Filho RA, Ferreira AM (2013) Uterine blood flow evaluation after artificial insemination on different uterine sites in mares. Animal Reproduction 10:615.

Azard A (2006) Caractérisation des systémes de production cunicole francais et perspectives d'évolution. Cuniculture Magazine 33:78-85.

Bansal AK, Bilaspuri GS (2011) Impacts of oxidative stress and antioxidants on semen functions. Veterinary Medecine International. doi: $10.4061 / 2011 / 686137$

Boiti C, Castellini M, Thau-Clément M, Besenfelder U, Liguori L, Renieri T, Pizzi F (2005) Guidelines for the handling of rabbit bucks and semen. World Rabbit Science 13:71-91.

Bonanno A, Mazza F, Alabiso M, Di Grigoli A, Alicata ML (2003) Effects of bio-stimulation induced by contact with buck on reproductive performance of rabbit does. Proc.: A.S.P.A. $15^{\text {th }}$ Congress, Parma, Italian Journal of Animal Science 2:133-135.

Brun JM, Theau-Clement M, Bolet G (2002) The relationship between rabbit semen characteristics and reproductive performance after artificial insemination. Animal Reproduction Science 70:139149.

Carluccio A, Robbe D, De Amicis I, Contri A, Tosi U, Russo F, Paoletti M (2004) Artificial insemination in rabbits: laboratory and field trial with three different semen extenders. World Rabbit Science 12:65-79.

Castellini C (1996) Recent advances in rabbit artificial insemination. Proc., $6^{\text {th }}$ World Rabbit Congress, Toulouse, France: 13-26.

Castellini C, Del Bosco A, Cardinali R (2006) Long term effect of post-weaning rhythm on the body fat and performance of rabbit doe. Reproduction Nutrition Development 46:195-204.

Castellini C, Dal Bosco A, Arias-Álvarez M, Lorenzo PL, Cardinalli R, Rebollar PG (2010) The main factors affecting the reproductive performance of rabbit does: a review. Animal Reproduction Science 122:174-182.

Cervantes MP, Palomino JM, Adams GP (2015) In vivo imaging in the rabbit as a model for the study of ovulation-inducing factors. Laboratory Animal 49:1-9.

Chen JLi, Simkin, ME, Yang, X, Foote RH (1989) Fertility of fresh and frozen rabbit semen inseminated at different times is indicative of male differences in capacitation time. Biology of Reproduction $41: 848-853$

Chelmońska B, Jerysz E, Lukaszewicz E, Kowalczyk A (2007) The effect of proctodeal gland foam, and depth and frequency of artificial insemination on fertility and hatchability of Japanese quail (Coturnix japonica). Turkish Journal of Veterinary and Animal Science 31:171-178. 
Conn PM, Crowley WF (1994) Gonadotropin-releasing hormone and its analogues. Annual Review of Medicine 45:391-405.

Cooper GW, Overstreet JW, Katz DF (1979) The motility of rabbit spermatozoa recovered from the female reproductive tract. Gamete Research 2:35-42.

Coy P, García-Vázquez FA, Visconti PE, Avilés M (2012) Roles of the oviduct in mammalian fertilization. Reproduction 144:649-660.

Daader AH, Yousef MK, Abdel-Samee AM, Abd El-Nour SA (2016) Recent trends in rabbit does reproductive management: special reference to hot regions. World Rabbit Science Association, Proc., $11^{\text {th }}$ World Rabbit Congress, Qingdao, China.

da Costa EP, da Costa AH, Macedo GG, Pereira EC (2011) Artificial Insemination in Swine. In: Manafi M (ed) Artificial Insemination in Farm Animals, InTech, Croatia, pp 95-114.

Daniel N, Renard JP (2010) Artificial insemination in rabbits. Cold Spring Harbor Protocols 2010:53-58. doi: 10.1101/pdb.prot5358.

Di Iorio M, Manchisi A, Rocco M, Chrenek P, Laffaldano N (2014) Comparison of different extenders on the preservability of rabbit semen stored at $5^{\circ} \mathrm{C}$ for 72 hours. Italian Journal of Animal Science 13:710-714. https://doi.org/10.4081/ijas.2014.3444

Dimitrova I, Angelov G, Teneva A, Uzev P (2009) Artificial insemination of rabbits. Biotechnology in Animal Husbandry 25:1249-1253.

Drobniz EZ, Overstreest JW (1992) Natural history of mammalian spermatozoa in the female reproductive tract. In: S.R. Mulligan (ed.) Oxford Reviews of Reproductive Biology, 14 Oxford Univ. Press, Oxford, pp. 1-45.

Echegaray-Torres JL, Olvera-Carmona JA, Salcedo-Baca R, Mendoza-Aendoza B (2004) Quality and fertility of preserved rabbit semen at $15{ }^{\circ} \mathrm{C}$, in gelatin supplemented extender. Proc., $8^{\text {th }}$ World Rabbit Congress, Puebla, Mexico.

Fischer B, Chavatte-Palmer P, Viebahn C, Navarrete Santos A, Duranthon V (2012) Rabbit as a reproductive model for human health. Reproduction 144:1-10

EL-Azzazi FE, Hegab IM, Hanafy AM (2017) Biostimulation and reproductive performance of artificially inseminated rabbit does (Oryctolagus cuniculus). World Rabbit Science 25:313-321.

El-Sabrout K (2017) Associations between single-nucleotide polymorphisms of melanocortin gene and sexual desire behavior in rabbit (Oryctolagus cuniculus). Journal of Veterinary Behavior 19:69-71. https://doi.org/10.1016/j.jveb.2017.02.005

El-Seadawy IE, El-Nattat WS, El-Tohamy MM, Aziza SA, ElSenosy YA, Hussein AS (2017) Preservability of rabbit semen after chilled storage in tris based extender enriched with different concentrations of propolis ethanolic extract (PEE). Asian Pacific Journal of Reproduction 6:68-76.

El-Sherbieny MA, Kalaba ZM, El-Siefy EM, Ragab AA (2012) Freezing and Fertilizing Capacity of Frozen Rabbit Semen Extended with Gelatin Addition. Asian Journal of Animal Science 6:291-299.

Farrell PB, Foote RH, Simkin ME, Clegg ED, Wall RJ (1993) Relationship of semen quality, number of sperm inseminated and fertility in rabbits. Journal of Andrology 14:464-471.

FAWC (2001) Interim Report on the Animal Welfare Implications of Farm Assurance Schemes. Farm Animal Welfare Council; London, UK.

Frandson RD (1981) Anatomy and Physiology of farm animals, Lea and Fibiger. Philadelphia, USA.
Gado H, Mellado M, Salem, AZ, Zaragoza A, Seleem TS (2015) Semen characteristics, sexual hormones and libido of Hy-Plus rabbit bucks influenced by dietary multi-enzyme additive. World Rabbit Science 23:111-120.

Gerencsér Zs, Matics Zs, Nagy I, Princz Z, Orova Z, Biró-Németh E, Radnai I, Szendr Zs (2008) Effect of a light stimulation on the reproductive performance of rabbit does. $9^{\text {th }}$ World Rabbit Congress, Verona - Italy, 371-374.

Gerencsér Zs, Matics Zs, Nagy I, Szendrő Zs (2011) Effect of light colour and reproductive rhythm on rabbit doe production. World Rabbit Science 19:161-170.

Gerencsér Zs, Matics Zs, Nagy I, Radnai I, Szendrő É, Szendrő Zs (2012) Effect of lighting program and nursing method on the production and nursing behaviour of rabbit does. World Rabbit Science 20:103-116.

González-Mariscal G, García Dalmán C, Jiménez A (2015) Biostimulation and nursing modify mating-induced c-FOS immunoreactivity in the female rabbit forebrain. Brain Research 1608:66-74.

Hamilton HH, Lukefahr SD, McNitt JI (1997) Maternal nest quality and its influence on litter survival and weaning performance in commercial rabbits. Journal of Animal Science 75:926-933.

Hammond J, Asdell SA (1926) The vitality of the spermatozoa in the male and female reproductive tracts. British Journal of Experimental Biology 4:155-185.

Hassan HE, Elamin KM, Yousif IA, Musa AM, Elkhairey MA, et al (2012) Evaluation of body weight and some morphometric traits at various ages in local rabbits of Sudan. Journal of Animal Science Advances 2:407-415.

Heba-Tallah AM, Osman MM, Elsheikh AI, ELNabititi AA (2016) Using rabbits as a model: artificial insemination as a tool to increase productive and reproductive traits. International Journal of Agriculture Innovations and Research 7:35-41.

Hegab IM, Kong SS, Yang SM, Mohamaden WI, Wei WH (2015) The ethological relevance of predator odors to induce changes in prey species. Acta Ethologica 18:1-9.

Hong S, Yu W, Kim Y, Cho J, Park M, Cho S, Yi H, Cho HJ, Shin H (2012) Development of a sperm preparation method for artificial insemination in rabbits. Journal of Animal and Veterinary Advances 11:712-718

Hudson R, Distel H (1990) Sensitivity of female rabbits to changes in photoperiod as measured by pheromone emission. Journal of Comparative Physiology 167:225-230.

Hussain A, Ahsan F (2005) The vagina as a route for systemic drug delivery. Journal of Controlled Release 103:301-313.

Iaffaldano N, Di Iorio M, Rosato, MP (2012) The cryoprotectant used, its concentration, and the equilibration time are critical for the successful cryopreservation of rabbit sperm: dimethylacetamide versus dimethylsulfoxide. Theriogenology 78:1381-1389.

Jentzer A (2008) Performances moyennes des élevages cunicoles en 2007. Présentation rapide des résultats renaceb et renalap. Cuniculture Magazine 35:39-44.

Jiménez P, Serrano-Meneses MA, Cuamatzi E, González-Mariscal G (2012) Analysis of sexual brhavior in male rabbits across successive tests leading to sexual exhaustion. World Rabbit Science 20:13-23.

Kim S, Lee YJ, Kim YJ (2011) Changes in sperm membrane and ROS following cryopreservation of liquid boar semen stored at 15 ${ }^{\circ} \mathrm{C}$. Animal Reproduction Science 124:118-124. 
Johinke D, de Graaf SP, Bathgate R (2015) The Effect of Sperm Concentration and Storage Vessel on Quercetin-Supplemented Rabbit Semen During Chilled Storage. Reproduction in Domestic Animals 50:567-573.

Rommers JM, Botti C, De Jong I, Brecchia G (2006) Performance and behaviour of rabbit does in a group-housing system with natural mating or artificial insemination. Reproduction Nutrition Development 46:677-687.

Kershaw-Young CM, Druart AD, Vaughan XJ, Maxwell WM (2012) Beta-Nerve growth factor is a major component of alpaca seminal plasma and induces ovulation in female alpacas. Reproduction, Fertility and Development 24:1093-1097.

Kumar D, Risam KS, Bhatt RS, Singh U (2013) Reproductive performance of different breeds of broiler rabbits under subtemperate climatic conditions, World Rabbit Science 21:169-173.

Kurykin J, Jaakma U, Waldmann A, Jalakas M, Aidnik M, Majas L, Padrik P (2006) Low semen dose intracornual insemination of cows at fixed time after PGF2 $\alpha$ treatment or at spontaneous estrus. Animal Reproduction Science 95:116-124.

Lavara R, Moce E, Lavara F, Viudes de Castro MP, Vicente JS (2005) Do parameters of seminal quality correlate with the results of on-farm inseminations in rabbits? Theriogenology 64:1130-1141.

Lawrence AB, Rushen J (1993) Stereotypic animal behaviour. fundamentals and applications to welfare. CAB International.

López-Gatius F, Sances G, Sancho M, Yániz J, Santolaria P, Gutiérrez R, Núñez M, Núñez J, Soler C (2005) Effect of solid storage at $15{ }^{\circ} \mathrm{C}$ on the subsequent motility and fertility of rabbit semen. Theriogenology 64:252-260.

Lorenzo PL, Garcia-Garcia RM, Arias-Alvarez M, Rebollar PG (2014) Reproductive and nutritional management on ovarian response and embryo quality on rabbit does. Reproduction in Domestic Animals 49:49-55.

Louis M (2009) Rabbit Biotechnology: Rabbit, Trnsqenesis, Cloning and Models Springer Science, Busines Media B.V. Springer Dordrecht Heidelberg, London, UK.

Lukefahr SD, Cheeke PR (1990) Rabbit project planning strategies for developing countries. (1) Practical considerations. Livestock Research for Rural Development 2:3.

Maertens L, Okerman F, De Groote G, Moermans R (1983) L'incidence de deux méthodes de traitement hormonal sur le comporment sexuel et la fertilité de jeunes lapines. Review Agriculture 36:167-175.

Maertens L, Luzi F (1995) Effect of diluent and storage time of rabbit semen on the fertility of does reared under two different lighting schedule. World Rabbit Science 3:27-34.

Mailafia S, Onakpa MM, Owoleke OE (2010) Problems and prospects of rabbit production in Nigeria, a review. Bayero Journal of Pure and Applied Sciences 3:20-25.

Marai IF, Habeeb AA, Gad AE (2002) Rabbits' productive, reproductive and physiological performance traits as affected by heat stress: a review. Livestock Production Science 78:71-90.

Marco-Jiménez F, Lavara R, Jiménez-Trigos E, Vicente JS (2013) In vivo development of vitrified rabbit embryos. Effects of vitrification device, recipient genotype, and asynchrony. Theriogenology 79:1124-1129.

Marongiu ML, Dimauro C (2013) Preliminary study on factors influencing rabbit doe reproductive efficiency: Effect of parity, day of mating, and suckling on ovarian status and estrogen levels at day
6 of pregnancy. Canadian Journal of Veterinary Research 77:126130.

Matics Zs, Gerencsér Zs, Radnai I, Mikó A, Nagy I, Szendrő Zs (2012) Effect of different lighting schedules (16 L:8 D or 12 L:6 D) on reproductive performance of rabbit does. Proc., $10^{\text {th }}$ World Rabbit Congress; Sharm El-Sheikh, Egypt.

McNitt JI (1992) Endocrinological approaches for commercial rabbit production. Journal of Applied Rabbit Research 15:364-397.

Mocé E, Vicente JS (2009) Rabbit sperm cryopreservation: A review. Animal Reproduction Science 110:1-24.

Morrel JM (1995) Artificial Insemination in Rabbits. British Veterinary 151:477-488.

Mousa-Balabel TM, Mohamed RA (2011) Effect of different photoperiods and melatonin treatment on rabbit reproductive performance. Veterinary Quarterly 31:165-171.

Ndors L, Ajuogu PK, Nyeche VN (2015) The assessment of artificial breeding pattern on fertility in rabbit does in the humid tropics. IOSR Journal of Agriculture and Veterinary Science 8:81-85.

Obasi KK, Lambe Z, Gbadamosi IT, Oyewopo AO (2016) A comparative study on the embryo-fetal development in rabbits after artificial insemination. Anatomy 10:106-113.

Ola SI, Oygbade MO (2012) Buck effect on rabbit oestrous, vulva colour, vaginal lumen cells and ovarian follicle populations. World Rabbit Science 20:71-79.

Ola SI, Olatunbosun OS (2013) Effect of buck presence on sexual receptivity and kindling performance of rabbit doe. Livestock Research for Rural Development 25:8.

Overstreet JW, Cooper GW (1978) Sperm transport in the reproductive tract of the female rabbit. I. The rapid transit phase of transport. Biology of Reproduction 19:101-114.

Paolicchi F, Urquieta B, Del Valle L, Bustos-Obregon E (1999) Biological activity of the seminal plasma of alpacas, stimulus for the production of LH by pituitary cells. Animal Reproduction Science $54: 203-210$

Peiró R, Santacreu MA, Climent A, Blasco, A (2007) Early embryonic survival and embryo development in two lines of rabbits divergently selected for uterine capacity. Journal of Animal Science 85:1634-1639.

Piles M, Rafel O, Ramon J, Varona L (2004) Genetic parameters of fertility in two lines of rabbits with different reproductive potential. Journal of Animal Science 83:340-343.

Quintela LA, Peña AI, Vega MD, Gullón J, Prieto C, Barrio M, Becerra JJ, Herradón PG (2009) Reproductive Performance of Rabbit Does Artificially Inseminated via Intravaginal Administration of [des-Gly 10, D-Ala6]-LHRH Ethylamide as Ovulation Inductor. Reproduction in Domestic Animals 44:829-833.

Raga-Ayat A, El-Sherbieny MA, El-Siefy EM, Adel-Khalek AE (2012) Effect of gelatin supplementation on the quality and fertility of rabbit spermatozoa preserved at room or refrigerator temperature degrees. Journal of Animal and poultry Production 12:579-588.

Ratto MH, Huanca W, Adams GP (2010) Ovulation- inducing factor: A protein component of llama seminal plasma. Reproductive Biology and Endocrin-ology 8:44.

Rebollar PG, Milanes A, Pereda N, Millan P, Cano P, Esquifino AI, Villarroel M, Silvan G, Lorenzo PL (2006) Oestrus synchronization of rabbit does at early post-partum by doe litter separation or ECG 
injection, Reproductive parameters and endocrine profiles. Animal Reproduction Science 93:218-230.

Rebollar PG (2011) Factors affecting efficacy of intravaginal ministration of $\mathrm{GnRH}$ analogues for ovulation induction in rabbit does. Giornate di Coniglicoltura ASIC, 35-45.

Renouf B, Klein S (2008) Identification des pratiques gagnantes des éleveurs les plus productifs en maternité. Journée Nationale du lapin de chair, 25 novembre 2008, pp. 53-62.

Richardson HN, Nelson AL, Ahmed EI, Parfitt DB, Romeo RD, Sisk CL (2004) Female pheromones stimulate release of luteinizing hormone and testosterone without altering GnRH mRNA in adult male Syrian hamsters (Mesocricetus auratus). General and Comparative Endocrinology 138:211-217.

Rodel HG, Bora A, Kaiser J, Kaetzke P, Khaschei M, von Holst D (2004) Density-dependent reproduction in the European rabbit: a consequence of individual response and age-dependent reproductive performance. OIKOS 104:3.

Rodríguez-de Lara R, Fallas-Lopez M, Rangel-Santos R, MariscalAguavo V, Martinez-Hernandez PA, Garcia-Muniz JG (2008) Influence of doe exposure ans season on reaction time and semen quality of male rabbits. Proc., $9^{\text {th }}$ World Rabbit Congress, Verona, Italy.

Rodríguez-de Lara R, Noguez-Estrada J, Rangel-Santos R, GarcíaMuñiz JG, Martínez-Hernández PA, Fallas-López M, MaldonadoSiman E (2010) Controlled doe exposure as biostimulation of buck rabbits. Animal Reproduction Science 122:270-275.

Rosato MP, Iaffaldano N (2011) Effect of chilling temperature on the long-term survival of rabbit spermatozoa held either in a trisbased or a jellified extender. Reproduction in Domestic Animals 46:301-308.

Rosato MP, Iaffaldano N (2013) Cryopreservation of rabbit semen: comparing the effects of different cryoprotectants, cryoprotectantfree vitrification, and the use of albumin plus osmoprotectants on sperm survival and fertility after standard vapor freezing and vitrification. Theriogenology 79:508-516.

Rowida MR, Osman RH, Mona HS (2015) Trials to improve the viability of rabbit semen at variable conditions of preservation using different diluents. Assiut Veterinary Medical Journal 61:160-168.

Rowida MR, Seleem TS, El-Kholy KH, Rawash ZM (2016) Effect of sperm concentration and site of insemination on conception rate of rabbits. Alexandria Journal of Veterinary Sciences 50:49-56.

Saleh SY, Attia KA, Fouad M, Nassar MM (2010) Effects of Multienzyme feed additive " Kemzyme" or/and Sodium Bentonite " as a feed Binder" on sexual activity and some fertility parameters of rabbit bucks. Journal of Agriculture Science 2:89-99.

Schmidova J, Milerski M, Svitakova A, Vostry L (2016) Effects of service ram on litter size in Romanov sheep. Small Ruminant Research 141:56-62.

Seleem TS (2003) Studies on productive and physiological characteristics of rabbits under different managerial conditions. Ph.D. Thesis, Faculty of Agric., Zagazig University, Zagazig, Egypt.

Seleem TS, Rowida MR (2005) Enzymatic activity and fertilizing ability of rabbit semen supplemented with nigella sativa extraction. The 4th Inter. Conf. on Rabbit Production in Hot Clim., Sharm ElSheikh, Egypt, pp 183-189.

Shuji K (2009) Improvement of Rabbit Production. In: Rabbit Biotechnology, Louis-Marie H, Jianglin F (eds.), Springer, Netherlands, pp 2-13.
Silva M, Fernández A, Ulloa-Leal C, Adams GP, Berland MA, Ratto MH (2015) LH release and ovulatory response after intramuscular, intravenous, and intrauterine administration of $\beta$-nerve growth factor of seminal plasma origin in female llamas. Theriogenology 84:10961102 .

Szendrő Zs, Rashwan AA, Bíró-Németh E, Radnai I (2006) Effect of vulva colour and turgidity on conception rate and litter size of rabbit does. Proc., $18^{\text {th }}$ Hung. Conf. Rabbit Prod.; Kaposvár, Hungary: 123126.

Szendrő Zs, Szendrő K, Dalle Zotte A (2012) Management of Reproduction on Small, Medium and Large Rabbit Farms: A Review. Asian-Australasian Journal of Animal Sciences 25:738-748.

Szendrő Zs, Gerencsér Zs, McNitt JI, Matics Zs (2016) Effect of lighting on rabbits and its role in rabbit production: A review. Livestock Science 183:12-18.

Tantasuparuk W, Manjarin R, Kirkwood RN (2011) Effect of site of sperm deposition on fertility when sows are inseminated with aged semen. Journal of Swine Health and Production 19:295-297.

Theau-Clément M, Boiti C, Bonanno A, Eiben Cs, Maertens L, Szendrő Zs (2006) Alternative methods for synchronisation of oestrus in lactating rabbit does. Recent advances in rabbit sciences (eds.). ILVO; Melle, Belgium: pp. 21-37.

Theau-Clément M (2007) Preparation of the rabbit doe to insemination: A review. World Rabbit Science 15:61-80.

Theau-Clément M (2008) Facteurs de réussite de l'insémination chez la lapine et méthodes d'induction de l'oestrus. INRA Production Animal 21:221-230.

Theau-Clément M, Bolet G, Fortun-Lamothe L, Brecchia G, Boiti C (2008) High plasmatic progesterone levels at insemination depress reproductive performance of rabbit does. Proc., $9^{\text {th }}$ World Rabbit Congress, Verona, Italy: 459-463.

Theau-Clément M, Tircazes, A, Saleil G, Monniaux D, Bodin L, Brun JM (2011) Etude préliminaire de la variabilité du comportement d'œstrus de la lapine. Proc., $13^{\text {èmes }}$ Journées de la Recherche Cunicole, 22-23 novembre 2011, Le Mans, France: 69-72.

Theau-Clément M, Weissman D, Davoust C, Galliot P, Souchet C, Bignon L, Fortun-Lamothe L (2012) Productivity and body composition of rabbit does subjected to three breeding systems. Proc., $10^{\text {th }}$ World Rabbit Congress, Sharm El- Sheikh, Egypt: 401405.

Theau-Clément M, Sécula A, Saleil G, Monniaux D, Brecchia G, Boiti C, Bodin L, Brun JM (2015) Genetic and non-Genetic factors affecting rabbit doe sexual receptivity as estimated from one Generation of divergent selection. World Rabbit Science 23:171-179.

Theau-Clément, M, Ailloud, E, Sanchez A, Saleil G (2016) Relationships between rabbit semen characteristics and fertilising ability after insemination. Animal 10:426-431.

Trocino A, Xiccato G (2006) Animal welfare in reared rabbits: a review with emphasis on housing systems. World Rabbit Science 14:77-93.

Tsai PS, Zhang L (2008) The emergence and loss of gonadotropin releasing hormone in protostomes: orthology, phylogeny, structure, and function. Biology of Reproduction 79:798-805.

Vella D, Donnelly TM (2012) Basic anatomy, physiology and husbandry. In: Ferrets, Rabbits, and Rodents: Clinical Medicine and Surgery. ( $2^{\text {nd }}$ ed.), Saunders, Philadelphia, pp 157-161. 
Vicente JS, Lavara R, Lavara F, Marco-Jimenez F, Viudes-de-Castro MP (2008) Rabbit reproductive performance after insemination with buserelin acetate extender. Livestock Science 115:153-157.

Zeidan EB, El-Zaiat EH, Rowida MR, El-Aasar TA (2008) Viability, acrosomal status and sex ratio of the centrifuged rabbit spermatozoa.
American-Eurasian Journal of Agricultural \& Environmental Sciences 4:318-325.

Zhao BT, Han D, Xu CL, Luo MJ, Chang ZL, Tan JH (2009) Protocol optimization for long-term liquid storage of goat semen in a chemically defined extender. Reproduction in Domestic Animals 44:865-872. 